\title{
Risk analysis of introduction and spread of huanglongbing in citrus groves in Rio Grande do Sul, Brazil
}

\author{
Manuela Sulzbach $^{1}$ (ID $\cdot$ Roberto Pedroso de Oliveira ${ }^{2} \cdot$ Eduardo Augusto Girardi $^{3}$. \\ Renato Beozzo Bassanezi ${ }^{4}$ - Francisco Ferraz Laranjeira ${ }^{3} \cdot$ Sergio Francisco Schwarz $^{1}$
}

Received: 2 May 2017 / Accepted: 10 October 2017

(C) Sociedade Brasileira de Fitopatologia 2017

\begin{abstract}
Huanglongbing (HLB), the most damaging disease of the citrus industry, is present in the Brazilian states of São Paulo, Minas Gerais and Paraná. The risks of introduction and spread of this A1 quarantine pest in citrus groves of the Rio Grande do Sul (RS) state were assessed based on a structured questionnaire composed of 27 questions applied to 163 growers in 35 municipalities. The locations were defined according to the economic relevance of citriculture, and the sample size (number of interviewed farmers) was proportional to the cultivated area in each municipality. A multi-criteria method was used to prioritize and assign weights to specific criteria associated with the different risks. Each farm was assigned to one of the four risk categories: low ( 0 to 0.25$)$, medium $(0.25$ to 0.50 ), high $(0.50$ to 0.75$)$ and very high $(0.75$ to 1.0$)$. The estimated risks of HLB introduction and spread in RS were mostly medium to high across the regions and farms within regions. Two factors, the presence of HLB in neighbor countries and citrus fruit transport from other regions mostly accounted for the risk of introduction of HLB into RS. Following an eventual
\end{abstract}

Section Editor: Harald Scherm

Manuela Sulzbach

manuela.sulzbach@ufrgs.br

1 Departamento de Horticultura e Silvicultura, Programa de Pós-Graduação em Fitotecnia, Faculdade de Agronomia, Universidade Federal do Rio Grande do Sul, Av. Bento Gonçalves, CEP 91540-000, Porto Alegre, RS 7712, Brazil

2 Embrapa Clima Temperado, Rodovia BR-392, Km 78, CEP 96010-971, Monte Bonito, Pelotas, RS, Brazil

3 Embrapa Mandioca e Fruticultura, Rua Embrapa, CEP 44380-000, Cruz das Almas, BA, Brazil

4 Fundo de Defesa da Citricultura, Av. Dr. Adhemar Pereira de Barros, CEP 14807-040, Araraquara, SP 201, Brazil introduction, the lack of knowledge about this pathosystem and the little or no use of insecticides were identified as the main contributors of disease spread within the state.

Keywords Citrus · 'Candidatus Liberibacter' · Diaphorina citri . Citrus greening $\cdot$ Quarantine pest

\section{Introduction}

Brazilian fruit production in 2015 exceeded 40 million tons, which corresponds to $6.1 \%$ of world production (FAO 2017). According to country's official statistics (IBGE 2017), citrus fruits are among the most consumed and cultivated in Brazil; in 2015 they occupied approximately 766,000 ha, producing more than 18.9 million tons of fruit. The country is the largest producer of oranges, accounting for about $30 \%$ of world production, followed by the USA and China (MAPA 2017a). In Brazil, citrus production is concentrated in São Paulo State, which accounts for about $77 \%$ of national production (IBGE 2017).

The state of Rio Grande do Sul (RS) is the sixth largest national citrus producer, with an estimated annual production of 505,000 tons distributed over more than 39,800 ha (IBGE 2017). Due to its edaphoclimatic conditions, RS allows for excellent production of high quality citrus fruits, especially regarding skin color and organoleptic qualities, suitable for fresh fruit market. The citriculture in RS is predominantly practiced by small growers, totaling 5000 farmers (EMATER/RS 2015).

Among the phytosanitary problems that occur in citrus, huanglongbing (HLB), also known as greening, is considered one of the most destructive bacterial diseases and is currently the main threat to the citrus industry worldwide (Bové 2006). Species of bacteria of the genus 'Candidatus Liberibacter' are the etiologic agents of HLB (Chen et al. 2009). HLB symptoms are related to the occurrence of three species, 'Ca. 
Liberibacter africanus', 'Ca. Liberibacter americanus' and 'Ca. Liberibacter asiaticus', the latter two with confirmed occurrence in Brazil (Teixeira et al. 2005). A phytoplasma belonging to the $16 \mathrm{SrDNA}-\mathrm{IX}$ group also causes symptoms very similar to HLB (Teixeira et al. 2008).

The spread of these bacteria is facilitated by insect vectors carrying the bacteria and and and man who produces stocks grafted with propagation material from infected plants and the movement of citrus plants and alternative infected hosts. The Asian citrus psyllid Diaphorina citri Kuwayama (Hemiptera: Liviidae) is the only known insect vector of bacteria associated with HLB in Brazil (Belasque et al. 2009). In addition to the Citrus genus and other related species, orange jasmine (Murraya paniculata (L.) Jack) is cited as preferred host of D. citri (Ikeda and Ashihara 2008) and it is a widely used as ornamental tree in Rio Grande do Sul.

For decades, HLB has been present in several countries of Asia and Africa, being reported in the Americas only in the first decade of the twenty-first century (Bové 2006). Its first report was precisely in the state of most citrus activity, São Paulo, in 2004 (Coletta-Filho et al. 2004). In the state of Minas Gerais it was recorded in 2005 (Castro et al. 2010) and in Paraná in 2006 (de Carvalho Nunes et al. 2010). More recently, HLB was confirmed in Misiones, Argentina, in 2012 (Outi et al. 2014), and in Paraguay in 2013 (COSAVE 2015).

Currently, disease control can be achieved by adopting three measures: use of disease-free tree stocks, elimination of diseased plants and control of insect vectors (Belasque et al. 2009). The effectiveness of these measures is much higher when performed in a coordinated manner and on a regional scale (Bassanezi et al. 2013). Given that curative or genetic control methods are not available for HLB management, the main measure to be adopted in HLB-free states Brazilian states is prevention. This can be done by adopting quarantine measures to prevent the entrance and establishment of HLB; stronger border control, preventing the entrance of citrus and M. paniculata stocks from states and countries with records of the disease; and inspection of fruit loads from locations with HLB reports, considering that the insect vector can be carried alive on loads of fruit coming from areas with occurrence of the disease (Halbert et al. 2010; Hall and McCollum 2011).

Multicriteria analysis has been highlighted as a tool to aid decision making in studies of different areas of knowledge, including agricultural sciences (Barros et al. 2007). This method allows the ranking of the criteria related to the object of study based on prior knowledge about the problem and its interrelationships (Saaty 2008). Therefore, to determine the hierarchy of the criteria affecting the risks of introduction and spread of HLB, it was necessary to obtain the participation of researchers in the areas of fruit growing and phytosanitary measures.

To date, Rio Grande do Sul has no record of HLB occurrence, but the presence of D. citri has been confirmed (SSV/ MAPA 2015). Considering that importance of the citriculture in the state, which is bordered by HLB-affected regions, the risk of introduction and spread, as well an overall risk (as weighted product of the two) of HLB in citrus-producing locations in RS were assessed based on survey data.

\section{Material and methods}

A structured questionnaire was applied during visits to citrus farms from August 2014 to December 2015. A total of 163 citrus farmers were surveyed from 35 municipalities in Rio Grande do Sul. The locations were selected based on the relevance of citrus activity for the local economy, while the number of interviewees on each municipality was defined according to the area cultivated with citrus.

Interviewees were selected through convenience sampling, a non-probabilistic sampling based on feasibility, where samples are selected according to proximity or availability (Duarte and Barros 2008). Among the selected municipality, those with up to 100 ha cultivated with citrus had one farmer interviewed; municipalities with 101 to 500 ha had at least three interviewed; 501 to 700 ha at least four; 701 to 1300 ha at least six; 1301 to 1600 ha ten; 1601 to 1900 ha had 14 interviewed, and more than 1900 ha had 18 interviewed (Table 1).

The municipalities covered by the survey are located within the main citrus-growing areas across seven regions: Vales dos Rios Caí and Taquari, Alto Uruguai, Serra, Noroeste, Alto Taquari, Sul and Fronteira Oeste (Table 1), according to a survey conducted previously by EMATER/RS (2015). A structured questionnaire with 27 pre-set closed questions was applied to the selected farms. The questions assessing the risk of HLB introduction and spread, and their respective significance (Table 2), were designed considering important factors that contribute to the epidemiology of HLB, based on studies such as those of Bové (2006) and Belasque et al. (2009, 2010). Closed questions are characterized by having a limited number of answers; in the case of this questionnaire, the response is binary: yes or no. Each affirmative answer (yes) had a different weight, while a negative response accounted for zero (0). The weights were obtained using the Analytic Hierarchy Process (AHP).

The AHP method (Saaty 2013) is used to prioritize and weight the importance of each criterion in the composition of risks (Table 2). AHP is a decision-making tool developed to support multi-criteria decision-making in which the problem is structured at hierarchical levels and the matched comparison of the criteria allows identifying inconsistencies (Saaty 2013).

The HLB risk to Rio Grande do Sul was structured in a hierarchy of three levels: the problem itself (level 1), the two basic risks leading to the problem - introduction and spread (level 2), and criteria composing each basic risk (level 3). Twelve such criteria were related to the risk of introduction and 15 to the risk of HLB spread in RS (Table 2). For both levels 2 and 3 , a group of six people performed pairwise comparisons 
Table 1 Municipalities of Rio Grande do Sul, Brazil, covered by the grower survey, their cultivated citrus area, production and number of citrus farmers interviewed by municipality

\begin{tabular}{|c|c|c|c|c|}
\hline Region & Municipality & $\begin{array}{l}\text { Cultivated } \\
\text { area (ha) }\end{array}$ & $\begin{array}{l}\text { Citrus } \\
\text { production (t) }\end{array}$ & $\begin{array}{l}\text { Number of } \\
\text { respondents }\end{array}$ \\
\hline \multirow{12}{*}{ Vales dos Rios Caí and Taquari } & Montenegro & 2720 & 42,400 & 18 \\
\hline & Pareci Novo & 1818 & 24,263 & 14 \\
\hline & São José do Sul & 1520 & 15,495 & 10 \\
\hline & Harmonia & 1069 & 9085 & 6 \\
\hline & São José do Hortêncio & 603 & 4780 & 6 \\
\hline & São Sebastião do Caí & 535 & 7306 & 5 \\
\hline & Tupandi & 515 & 1980 & 5 \\
\hline & Triunfo & 414 & 1608 & 4 \\
\hline & Portão & 405 & 3150 & 5 \\
\hline & Maratá & 320 & 2610 & 3 \\
\hline & Brochier & 247 & 1425 & 3 \\
\hline & Barão & 18 & 45 & 1 \\
\hline \multirow[t]{2}{*}{ Alto Taquari } & Arvorezinha & 316 & 85 & 3 \\
\hline & Anta Gorda & 270 & 520 & 3 \\
\hline \multirow[t]{11}{*}{ Alto Uruguai } & Planalto & 1374 & 470 & 10 \\
\hline & Liberato Salzano & 1260 & 250 & 8 \\
\hline & Alpestre & 718 & 1360 & 7 \\
\hline & Itatiba do Sul & 665 & 650 & 4 \\
\hline & Aratiba & 657 & 1158 & 4 \\
\hline & Severiano de Almeida & 430 & 450 & 3 \\
\hline & Mariano Moro & 419 & 864 & 3 \\
\hline & Marcelino Ramos & 328 & 1710 & 3 \\
\hline & Constantina & 282 & 307 & 4 \\
\hline & Maximiliano de Almeida & 173 & 154 & 3 \\
\hline & Três Arroios & 103 & 96 & 3 \\
\hline \multirow[t]{4}{*}{ Serra } & Veranópolis & 436 & 4806 & 4 \\
\hline & Caxias do Sul & 290 & 1050 & 4 \\
\hline & Bento Gonçalves & 243 & 1476 & 3 \\
\hline & Catuípe & 85 & 300 & 1 \\
\hline \multirow[t]{3}{*}{ Noroeste } & Ijuí & 31 & 93 & 2 \\
\hline & Santo Cristo & 12 & 170 & 1 \\
\hline & Bozano & 3.5 & 0 & 1 \\
\hline Sul & Pelotas & 235 & 350 & 3 \\
\hline \multirow[t]{2}{*}{ Fronteira Oeste } & Rosário do Sul & 475 & 2396 & 3 \\
\hline & Uruguaiana & 105 & 43 & 3 \\
\hline Total & & $19,094.5$ & 132,905 & 163 \\
\hline
\end{tabular}

using a scale ranging from 1 (options are equally important) to 9 (one option is extremely more important than the alternative). The comparisons were used to generate a pairwise comparison matrix with the chosen intensities. Such matrix was used to calculate the eigenvector of the options in each hierarchy level. Then, the priorities (weights) for each criterion were established, as well as the consistency ratio (CR). This ratio is defined as $\mathrm{CR}=\mathrm{CI} / \mathrm{RI}$, where $\mathrm{CI}$ is the consistency index of the case matrix, and $\mathrm{RI}$ is the consistency index of a random matrix of the same size. Values below $10 \%(0.1)$ are considered to be very consistent. $\mathrm{CR}>90 \%(0.9)$ indicates the process is nearly random (Saaty 2013). All computations were performed using the AHP Online System (bpmsg.com) (Goepel 2013).

The risks of introduction and spread of HLB for each farm and the combination of the two risks, obtained by calculation: (introduction risk $\mathrm{x}$ introduction weight $)+($ spread risk $\mathrm{x}$ spread weight), referred to as overall risk towards HLB, were calculated. The estimated risks were assigned to one of four risk categories: low ( 0 to 0.25 ), medium ( 0.2501 to 0.50$)$, high $(0.5001$ to 0.75$)$ and very high $(0.7501$ to 1.0$)$. A linear mixed model analysis (using the lme4 package of R statistical computing environment) was used test the hypothesis that the means of the risks across farms within a region did not differ among regions. In the model, region was treated as fixed factor and farms within region as random effects. Deviance analysis tested the significance of the fixed effects using a Wald test at $5 \%$ probability $\left(P>\chi^{2}\right)$. Additionally, we estimated the risks for a scenario where HLB was already present at a given location of RS, i.e., in which questions 1 and 2 for risk of introduction (Table 2) were positive and constant.

\section{Results}

\section{AHP results}

For the second level of the hierarchy, the group consensus was very high $(88 \%)$ with a consistency ratio (CR) of $0 \%$. The priorities (weights) were 0.762 for introduction and 0.238 for spread. For the third hierarchical level, criteria were 
Table 2 Structured questionnaire used in the grower survey, with 27 pre-set closed questions divided into two sections corresponding to the risks of huanglongbing (HLB) introduction and spread in the State of Rio Grande do Sul, Brazil, and the weight associated to each criterion based on the Analytical Hierarchy Process (AHP)

\begin{tabular}{|c|c|c|c|c|}
\hline \multirow[t]{2}{*}{ No } & \multirow[t]{2}{*}{ Question } & \multirow[t]{2}{*}{ Significance } & \multicolumn{2}{|c|}{$\begin{array}{l}\text { Weight by } \\
\text { question at } \mathrm{AHF}\end{array}$} \\
\hline & & & $\begin{array}{l}\text { Local } \\
\text { priority }\end{array}$ & $\begin{array}{l}\text { Global } \\
\text { priority }\end{array}$ \\
\hline \multicolumn{5}{|c|}{ Risk of HLB introduction (weight 0.7621 ) } \\
\hline 1 & Does HLB occur in the area and state? & The presence of HLB in the area favors a fast dissemination of the disease. & 0.2502 & 0.1910 \\
\hline 2 & Does Diaphorina citri occur in the area? & The presence of the HLB vector in the area increases the risk of disease introduction. & 0.1554 & 0.1180 \\
\hline 3 & Does HLB occur in a neighboring country? & $\begin{array}{l}\text { D. citri has great mobility, either by flight or wind, and can move from the vicinity } \\
\text { where HLB occurs. }\end{array}$ & 0.1044 & 0.0800 \\
\hline 4 & Are there official plant health actions in the area? & Official plant health actions plays a major role for the prevention of quarantine pests. & 0.0532 & 0.0410 \\
\hline 5 & Are tree stocks produced in another location? & Movement of tree stocks among producing areas favors the introduction of HLB. & 0.0409 & 0.0310 \\
\hline 6 & $\begin{array}{l}\text { Is the area of origin of the tree stocks affected by } \\
\text { HLB? }\end{array}$ & $\begin{array}{l}\text { The use of infected tree stocks is one of the main means of HLB introduction in new } \\
\text { areas. }\end{array}$ & 0.1255 & 0.0960 \\
\hline 7 & $\begin{array}{l}\text { Are tree stocks produced outside of a protected } \\
\text { environment? }\end{array}$ & Insect-proof nurseries are mandatory for the production of healthy stocks. & 0.0630 & 0.0480 \\
\hline 8 & $\begin{array}{l}\text { Are there orange jasmine plants in the area } \\
\text { (farm, neighbors, city)? }\end{array}$ & Orange jasmine is the preferred host of $D$. citri. & 0.0354 & 0.0270 \\
\hline 9 & $\begin{array}{l}\text { Is there incoming/outgoing movement of fruit } \\
\text { at the location for areas affected by HLB? }\end{array}$ & $\begin{array}{l}\text { D. citri can be carried within fruit loads moving between an infected area and the } \\
\text { location. }\end{array}$ & 0.0598 & 0.0460 \\
\hline 10 & $\begin{array}{l}\text { Is the citrus density in the neighborhood greater } \\
\text { than ten production units? }\end{array}$ & $\begin{array}{l}\text { Areas with more citrus growers in the neighborhood favor the risk of HLB introduction } \\
\text { as a result of differentiated management and increased inoculum potential. }\end{array}$ & 0.0317 & 0.0240 \\
\hline 11 & $\begin{array}{l}\text { Is the distance from other areas with citrus less } \\
\text { than } 1 \mathrm{~km} \text { ? }\end{array}$ & Closer groves favor the introduction of HLB once primary infection has occurred. & 0.0541 & 0.0410 \\
\hline 12 & $\begin{array}{l}\text { Is the production center cut by federal/interstate } \\
\text { access roads? }\end{array}$ & $\begin{array}{l}\text { The presence of roads near the groves facilitates the introduction of both D. citri and HLB } \\
\text { in new areas. }\end{array}$ & 0.0262 & 0.0200 \\
\hline \multicolumn{5}{|c|}{ Risk of HLB spread (weight 0.2379 ) } \\
\hline 1 & $\begin{array}{l}\text { Is the producer unaware of HLB and Asian } \\
\text { citrus psyllid? }\end{array}$ & $\begin{array}{l}\text { Lack of knowledge of the pathosystem and symptoms delays the identification of HLB } \\
\text { in the field and the adoption of preventive measures. }\end{array}$ & 0.200 & 0.0480 \\
\hline 2 & $\begin{array}{l}\text { Does the producer use little or no chemicals to } \\
\text { control citrus pests? }\end{array}$ & $\begin{array}{l}\text { The chemical control } \mathrm{f} D \text {. citri is essential to manage HLB spread, and growers used to } \\
\text { this practice will promptly adopt. }\end{array}$ & 0.1266 & 0.0300 \\
\hline 3 & Are windbreaks absent? & The absence of windbreaks favors the dispersion of $D$. citri among orchards. & 0.0375 & 0.0090 \\
\hline 4 & Is cultivation limited to only one citrus cultivar? & $\begin{array}{l}\text { Single cultivar groves present similar phenological stages which facilitates psyllid } \\
\text { control; on the other hand, citrus monoculture increases the risk of HLB infection } \\
\text { for the propriety. }\end{array}$ & 0.0228 & 0.0050 \\
\hline 5 & $\begin{array}{l}\text { Is the average productivity per cultivar less than } \\
20 \text { tons per ha? }\end{array}$ & $\begin{array}{l}\text { Low yields lead to decreased income which in turn reduces the potential of adoption } \\
\text { of HLB control technologies. }\end{array}$ & 0.0504 & 0.0120 \\
\hline 6 & $\begin{array}{l}\text { Does the producer have difficulties in monitoring } \\
\text { pests? }\end{array}$ & $\begin{array}{l}\text { Limitations in pests monitoring indicate that the citrus grower will unlikely identify } \\
\text { the presence of } D \text {. citri. }\end{array}$ & 0.1280 & 0.0300 \\
\hline 7 & Is the planting density less than 600 plants per ha? & $\begin{array}{l}\text { High citrus tree density increases HLB progress if there is no vector control. On the } \\
\text { other hand, HLB resets are less necessary and yield decrease is lower as a result } \\
\text { of the decreased production per tree. }\end{array}$ & 0.0271 & 0.0060 \\
\hline 8 & Is there use of irrigation? & Irrigation induces higher vegetative vigor to citrus trees which may attract $D$. citri. & 0.0213 & 0.0050 \\
\hline 9 & $\begin{array}{l}\text { Are there groves aged less than or equal to } \\
6 \text { years? }\end{array}$ & $\begin{array}{l}\text { Young citrus trees are more attractive to } D \text {. citri and are more sensitive to HLB, } \\
\text { becoming unproductive very fast. }\end{array}$ & 0.0763 & 0.0180 \\
\hline 10 & $\begin{array}{l}\text { Are there plants with symptoms of nutritional } \\
\text { deficiencies? }\end{array}$ & HLB symptoms can be mistaken with several nutritional deficiencies. & 0.0510 & 0.0120 \\
\hline 11 & $\begin{array}{l}\text { Is the property disassociated with } \\
\text { cooperatives/associations? }\end{array}$ & $\begin{array}{l}\text { Growers that are used to any level of associations are more likely to coordinate HLB } \\
\text { management in an area-wide approach which is more efficient for the disease control. }\end{array}$ & 0.0434 & 0.0100 \\
\hline 12 & $\begin{array}{l}\text { Are cooperatives/associations unavailable in the } \\
\text { area? }\end{array}$ & $\begin{array}{l}\text { Synchronized D. citri control and eradication of HLB symptomatic trees are more } \\
\text { efficient if the neighboring orchards are associated. }\end{array}$ & 0.0447 & 0.0110 \\
\hline 13 & $\begin{array}{l}\text { Does the property not go through a certification } \\
\text { process? }\end{array}$ & $\begin{array}{l}\text { Certified orchards are frequently audited for an improved integrated pest management } \\
\text { program. }\end{array}$ & 0.0440 & 0.0100 \\
\hline 14 & Is technical assistance unavailable? & $\begin{array}{l}\text { Available and trained technical assistance is critical for grower support in HLB } \\
\text { identification, scouting and management. }\end{array}$ & 0.0915 & 0.0220 \\
\hline 15 & $\begin{array}{l}\text { Is the citrus industry's economic return } \\
\text { unsatisfactory for the producer? }\end{array}$ & $\begin{array}{l}\text { The dissatisfaction with the economic return may lead to decreased use of control } \\
\text { measures and even to abandoned orchards which highly increase inoculum sources } \\
\text { and consequently HLB spread. }\end{array}$ & 0.0353 & 0.0084 \\
\hline
\end{tabular}

Local priority is the weight of each criterion within either introduction or spread risk. Global priority is the weight of each criterion modulated by the weight of each risk. For example, criterion 15 is related to HLB spread risk which has a weight of 0.2379 . The local priority (weight) of criterion 15 is 0.0353 . Thus its global priority is 0.0084 (risk weight $\mathrm{x}$ local priority)

compared within basic risks. The pairwise comparisons among Introduction criteria had a moderate group consensus of $73 \%$ and a $\mathrm{CR}=1.1 \%$. The weights for each criterion varied from 0.0262 to 0.2502 (Table 2). The group consensus for spread criterion was $64 \%$ with a $\mathrm{CR}=1.2 \%$. The criteria weights varied between 0.0213 and 0.2 (Table 2). The overall group consensus for the entire process was $79 \%$, with individual CRs ranging from $1.2 \%$ to $12.4 \%$. 


\section{Risk of HLB introduction}

The contribution of each criterion to the composition of the risks of introduction and spread of HLB was calculated by relating the mean of affirmative response obtained in the questionnaire applied to visit the farms, multiplied by the weight defined by the AHP for the criterion. When evaluating the contribution of each criterion to the risk of HLB introduction (Fig. 1a), we found that absence of HLB in any area of the state was the main factor reducing this risk. HLB presence would imply an increase of about $68 \%$ in the risk of HLB introduction, according to calculated relation between the weight obtained by AHP analysis and positive frequency throughout the state (Table 2).

The presence of HLB in a neighboring country was the main contributing factor. The movement of fruit from regions with HLB to RS was the second most important component factor for the introduction risk, followed by nursery trees produced outside a protected environment (third factor). Next, the proximity equal to or less than $1 \mathrm{~km}$ between citrus farms was the fourth most important factor and the absence of disease management was ranked fifth in the composition of HLB introduction risk. The sum of these five factors adds up to $73 \%$ of total risk of HLB introduction to RS.

Based on this weighting of risk factors for HLB introduction to citrus farms of RS, ten citrus farm were classified as having low risk of disease introduction based on survey responses, 145 as having medium risk, and 8 were classified as high risk (Fig. 2). In the scenario of the presence of the disease in the state and municipalities, the introduction risk increased to $4.9 \%$ classified as very high and $87.7 \%$ classified as high risk (Fig. 2).

\section{Risk of HLB spread}

Based on AHP, the major factor for HLB spread risk was the lack of knowledge about this pathosystem among farmers interviewed, as well as about its insect vector (Fig. 1b).
Fig. 1 Relative importance of questionnaire criteria for the calculation of the risk of introduction (a) and spread (b) of huanglongbing (HLB) in surveyed citrus farms in Rio Grande do Sul, Brazil. The relative importance is the mean of the positive frequency of each criterion in farms multiplied by its weight obtained by the Analytical Hierarchy Process multicriteria analysis method (local priority)

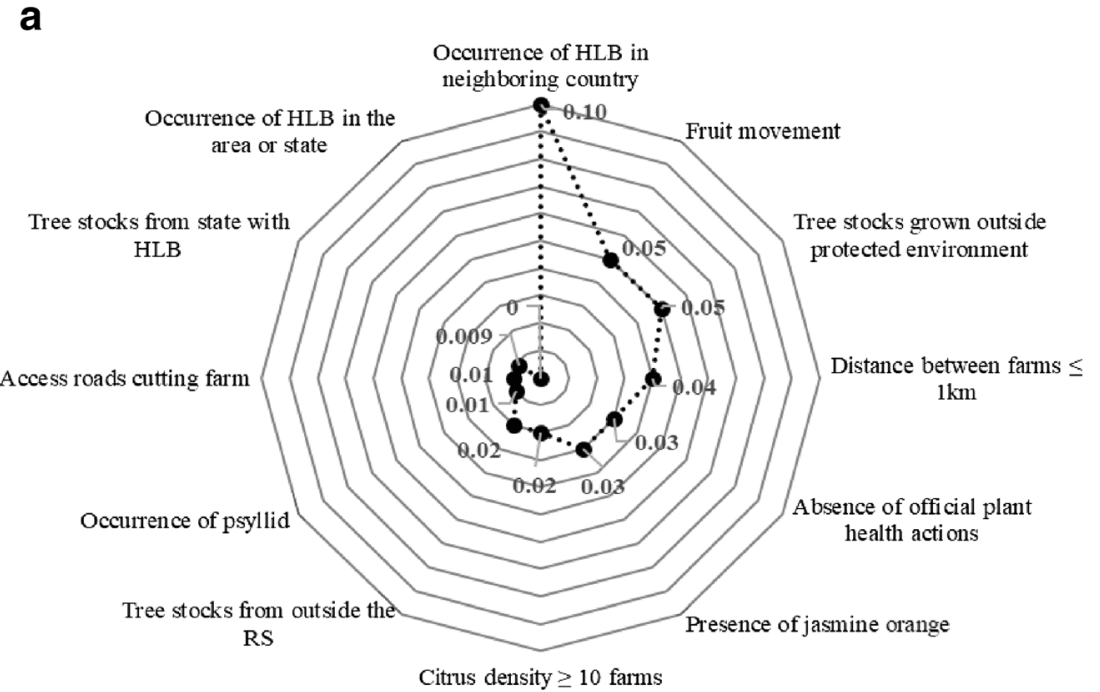

b

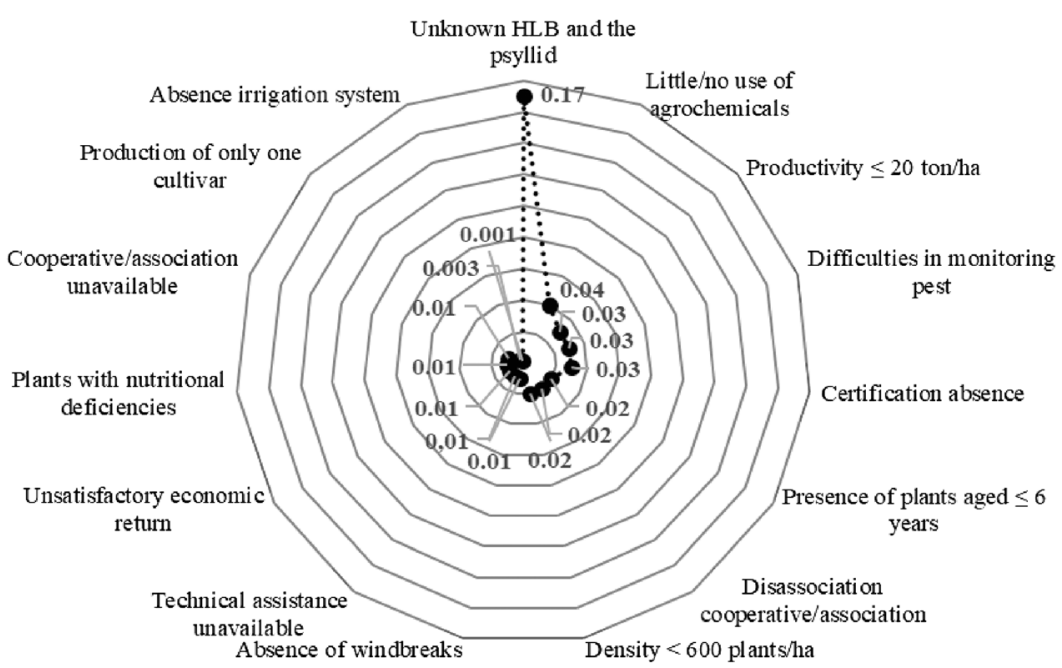


Fig. 2 Proportion of citrus groves ( $\mathrm{n}=163$ farms) in Rio Grande do Sul (RS), Brazil, classified according to three different risks of huanglongbing (HLB) in four risk categories based on the risk value: very high (0.7501 to 1.0$)$, high ( 0.5001 to $0.75)$, medium ( 0.2501 to 0.50 ) and low ( 0 to 0.25$)$. The three risks estimated are introduction risk in the scenario of presence or absence of HLB and the spread risk

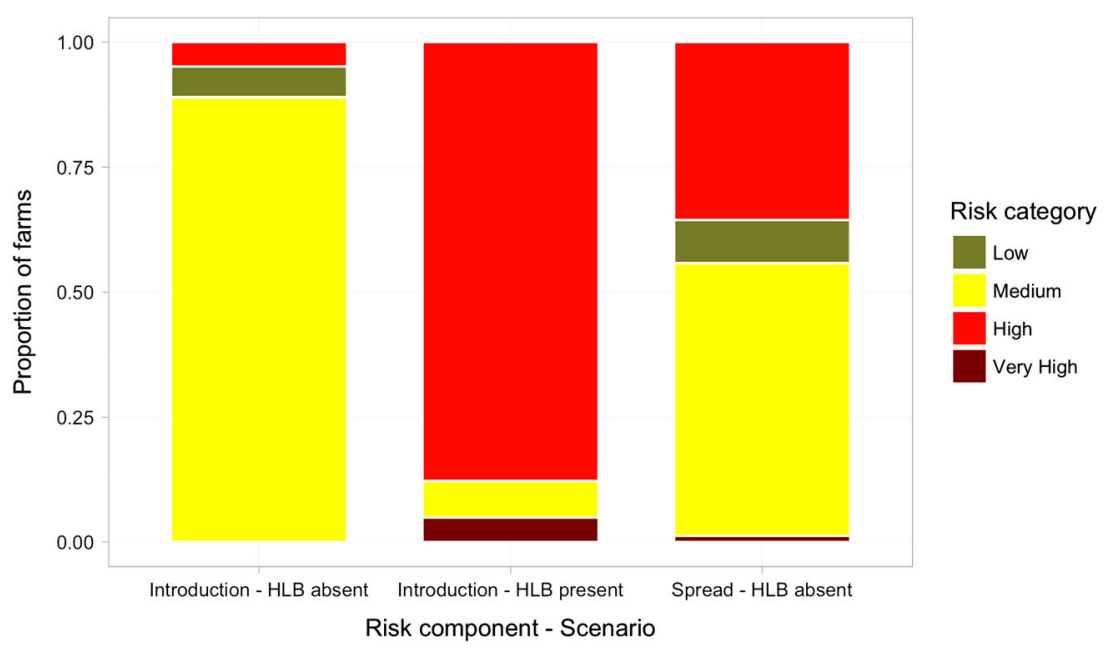

Little/no use of agrochemicals was the second most important factor, followed by productivities equal to or less than 20 tons per ha, which constitute the third factor of importance in HLB spread risk. The fourth factor considered in risk composition of HLB spread was related to difficulties in vector monitoring by growers on their farms. In addition, the fifth factor was absence of any kind of citrus farm certification in RS. As for the risk of HLB spread in RS, 14 farms were classified as low risk of disease spread, 89 as medium risk, 58 as high risk, and only two as very high risk (Fig. 2), if this disease were introduced in the state.

\section{Overall risk}

The combined risk of introduction and spread, or the overall HLB risk, varied among municipalities within regions and among regions of the state (Fig. 3). The effect of region was considered of marginal significance according the mixed modeling analysis $(P=0.0629)$. The overall risk ranged from 0.33 to 0.43 across the six regions, or mostly in the medium risk category (Figs. 3 and 4a). The overall means estimate for the state was 0.40 (CI95\% 0.37-0.42), which is within the medium risk category.

The risk of introduction across farms was mostly medium (Fig. 4a). However, the spread risk was estimated from medium to high, because half of them were ranked as medium based on survey responses (Fronteira Oeste, Noroeste and Vales dos Rios Caí and Taquari) and the remaining areas were ranked as high (Alto Uruguai, Serra Gaúcha and Sul). There is a large number of municipalities with a high risk of disease spread (Fig. 4b).

Introduction risk estimates in a scenario where HLB is present in any area of Rio Grande do Sul would lead to $87.7 \%$ of farms with high introduction risk and $4.9 \%$ with

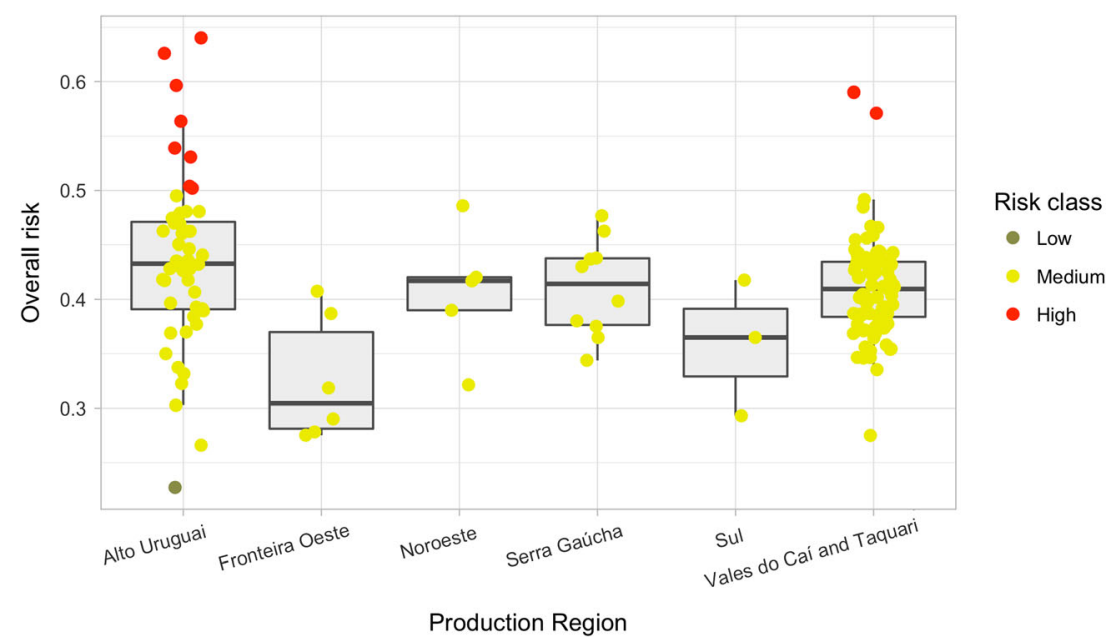

Fig. 3 Distribution of the overall risk [(introduction risk $\mathrm{x}$ introduction weight $)+($ spread risk $x$ spread weight)] of huanglongbing (HLB) within each of the six citrus-producing regions of Rio Grande do Sul, Brazil, based on a survey applied to citrus growers $(n=163$ farms). Each dot represents a farm and its color represents the respective risk class: very high ( 0.7501 to 1.0$)$, high ( 0.5001 to 0.75$)$, medium ( 0.2501 to 0.50$)$ and low ( 0 to 0.25 ). The box comprises $50 \%$ of the observations. Vales $=$ Vales do Caí e Taquari 


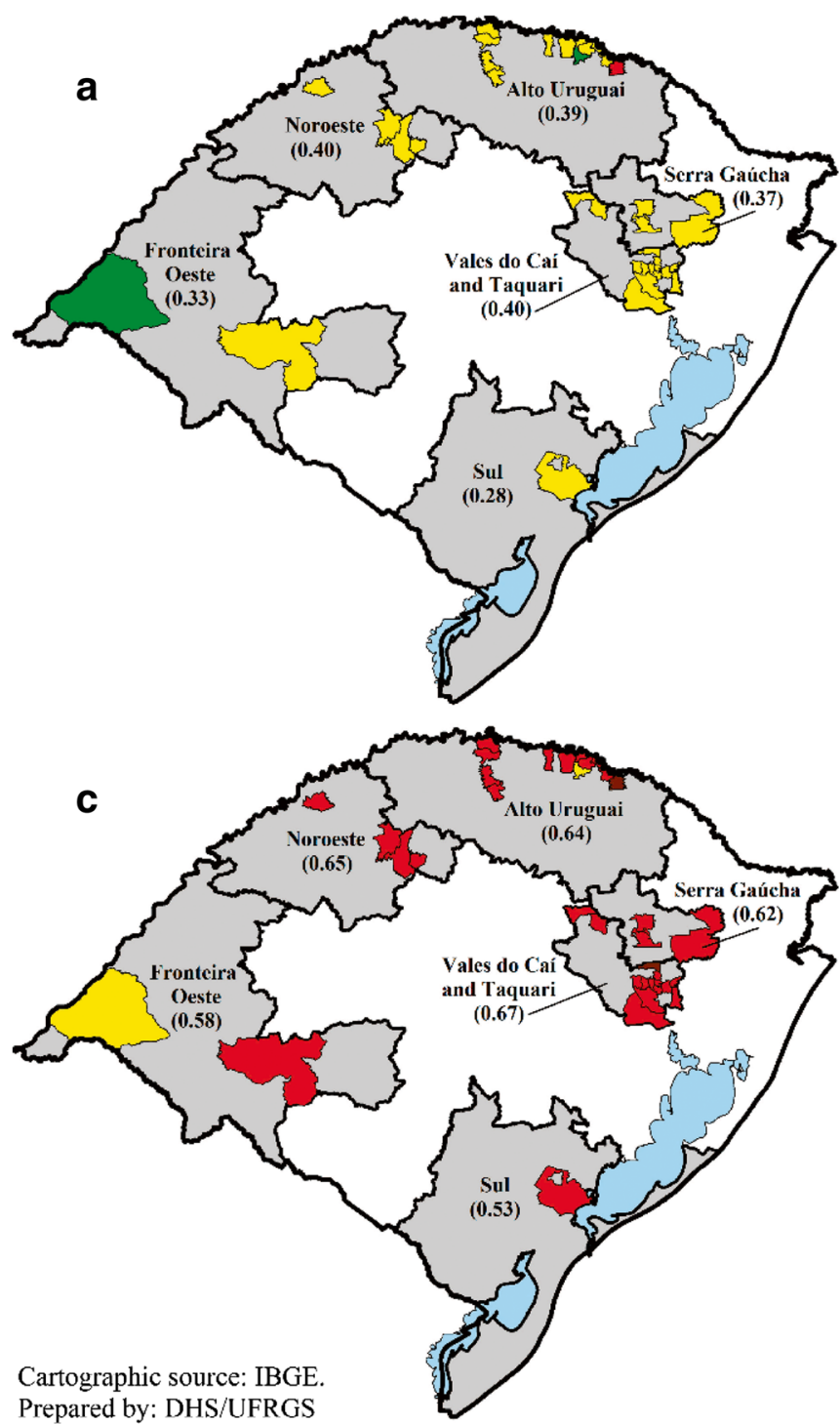

Prepared by: DHS/UFRGS

Fig. 4 Classification of the 35 municipalities included in the grower survey in Rio Grande do Sul (RS), Brazil, regarding the risk towards huanglongbing (HLB). Values in parentheses give the average values of

very high risk (Fig. 2), i.e. there would be a significant increase in introduction risk for the evaluated lands (Fig. 4c). As for the observed overall risk, just one farm showed a low risk concerning HLB, 151 had a medium overall risk and 11 exhibited a high overall risk (Fig. 3). Thus, 93\% of the surveyed citrus production farms presented an overall medium risk towards HLB, confirming that this disease is an important threat to the state's citrus industry.

\section{Discussion}

The presence of HLB in neighboring countries is of concern considering that the vector $D$. citri can fly more than $1 \mathrm{~km}$ in 47 to 49 min (Arakawa and Miyamoto 2007). Martini et al.
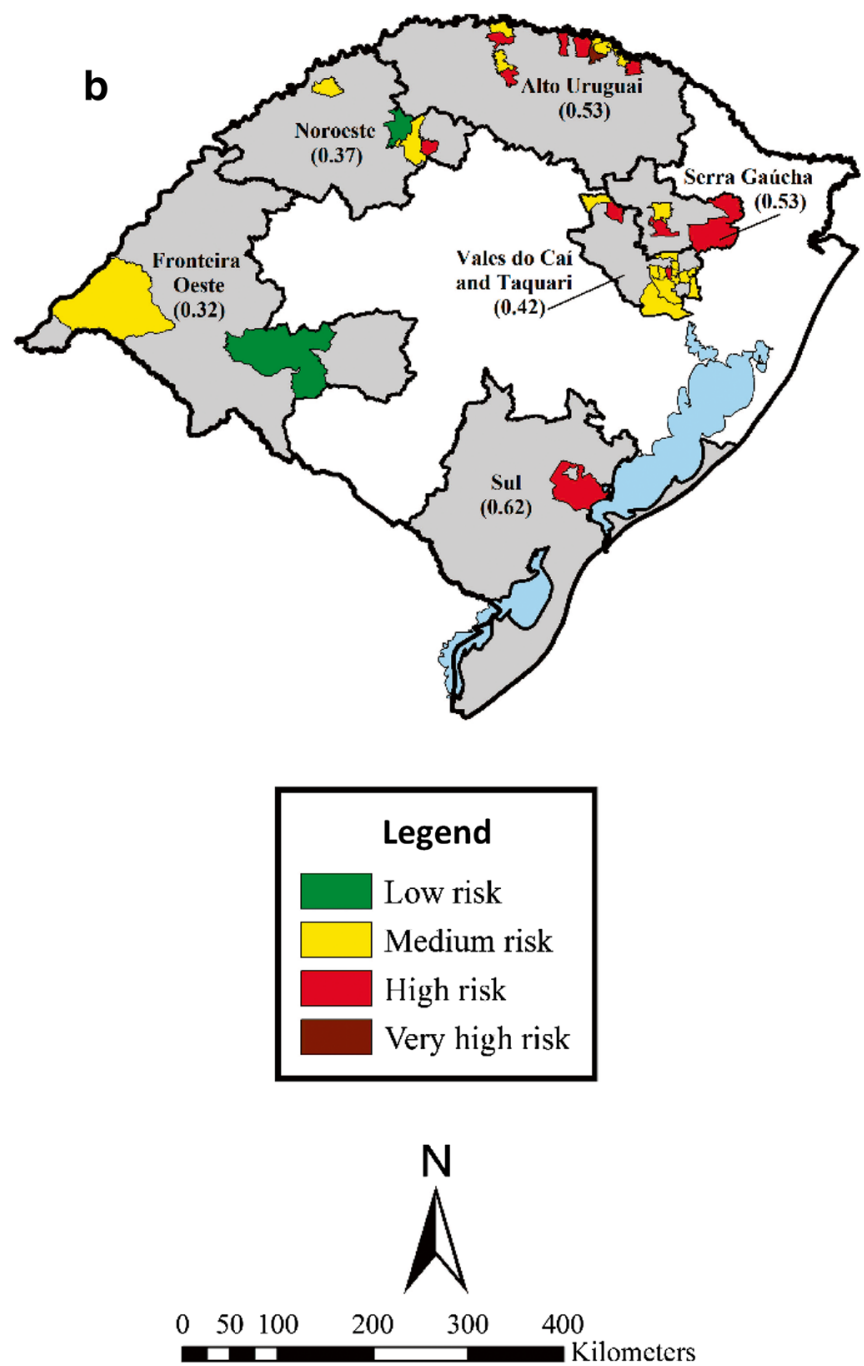

Geographic System

Horizontal Datum: SIRGAS 2000

the risk of the six major production regions. (a) Risk of introduction of HLB; (b) Risk of spread of HLB; (c) Risk of introduction of HLB, considering the scenario where HLB is already present in any region of RS

(2014) measured the continuous flight of $D$. citri up to $3 \mathrm{~h}$ corresponding to a distance of approximately $2.4 \mathrm{~km}$. But D. citri may be able to move even longer distances depending on the wind, since it has weak wing muscles in relation to wing size (Sakamaki 2005). According to Kobori et al. (2011), wind is its main form of dispersion. Assuming D. citri migrates primarily with the wind, the municipalities closest to the region with disease occurrence are at higher risk of introduction than the others, justifying the first factor as the most important for HLB introduction risk.

The movement of fruit from regions with HLB to RS is dangerous due to the possibility of psyllids surviving for up to 13 days when transported in fruit loads, as reported by Halbert et al. (2010) and Hall and McCollum (2011), where in the presence of leaves can extend the survival for up to 
30 days. The absence of state rules requiring phytosanitary certification of fruit loads from states with records of the disease reinforces the importance of this criterion in determining HLB introduction risk. Furthermore, this also highlights the fragility of state phytosanitary barriers in relation to this A1 quarantine pest for RS.

Nursery trees produced outside a protected environment were considered an important factor for risk of HLB introduction; as already known, they are components of great importance in relation to the phytosanitary health of the grove. According to Schäfer et al. (2001), nursery stock is the most important and expensive input for establishing a citrus grove. In RS, decree No. 65/2004 of the Secretary of Agriculture, Livestock and Supply determines that citrus stock should be produced exclusively in nurseries with insect-proof screens; however the production of unscreened stock persists in about 100 nurseries in the state and only nine nurseries are producing in a protected environment (de Oliveira and Carvalho 2016).

The proximity between farms, common in the RS citrus production system, can favor the rapid spread of the disease between farms. Therefore, the proximity between farms equal to or less than $1 \mathrm{~km}$ was highlighted among the factors determining HLB introduction risk in RS. In São Paulo state, even farms performing HLB management have become unproductive and uneconomic when located less than $2 \mathrm{~km}$ from those without management, since the latter act as an external inoculum source of 'Ca. Liberibacter asiaticus' (Belasque et al. 2009).

The absence of official plant health actions was the fifth factor in composition of HLB introduction risk. Its importance is evident when considering the second main criterion mentioned above, the movement of fruit loads, as well the presence of orange jasmine trees, which occur in Brazilian regions with the presence of the disease and are also shipped to Rio Grande do Sul. The absence of official plant health actions also demonstrates difficulties in inspecting phytosanitary borders, since plant management agencies, which monitor the psyllid and sample plants with suspect symptoms, are not able to inspect most of the citrus farms visited. Once the disease is present in the state and municipalities, the risk of HLB introduction to the citrus farms would increase considerably. This scenario simulation shows that any unknown presence of HLB in RS results in a significant magnification of its likelihood of spread and implies the need for maintenance of surveillance activities in the state.

Concerning HLB spread, the lack of information on characteristic symptoms of the disease, as well as on factors related to its management, such as spread, vector control and detection, can delay the identification of disease presence and the immediate adoption of control measures. As a result, these factors allow disease spreading from the point of introduction. This situation demonstrates the local producers' unpreparedness towards facing the currently most important disease in the citrus industry.
Several strategies have been studied to control D. citri, such as the use of natural enemies, entomopathogens, and repellent compounds, among others. However, to date, intensive chemical control is the most used method of $D$. citri control, fundamental to most programs of HLB management (Tiwari et al. 2011). For this reason, little/no use of agrochemicals was the second factor for HLB spread risk.

In relation to yield, only $32 \%$ of farmers interviewed had yields equal to or greater than $20 \mathrm{t} \mathrm{ha}^{-1}$. The average yield of groves in São Paulo, according to the IBGE, was $29.7 \mathrm{t} \mathrm{ha}^{-1}$ for oranges and $31.4 \mathrm{t} \mathrm{ha}^{-1}$ for mandarins in 2015 . However, the yield calculated for the same period (2015) in São Paulo was $14.3 \mathrm{t} \mathrm{ha}^{-1}$ for oranges and $11.8 \mathrm{t} \mathrm{ha}^{-1}$ for mandarins, according to IBGE (2017). Low yields imply a smaller production scale and indicate less use of technology. Thus, less funds will be available for investment, which will compromise HLB management. Hence, an increase in production costs can be observed, as noted in states where the disease is present.

Although RS is free of 'Ca. Liberibacter 'spp. so far, the psyllid is present in most municipalities in urban areas on orange jasmine or citrus plants, as recorded in Porto Alegre (2011-2015), Santa Cruz do Sul (2013-2015), Ijuí (20132014), Crissiumal (2013), Horizontina (2013), Humaitá (2015) and Três de Maio (2015) (SSV/MAPA 2015). Its presence in citrus groves located in the countryside occurred only in Marcelino Ramos (2009), Maximiliano de Almeida (2009) and Rosário do Sul (2010-2014) (SSV/MAPA 2015). The evidence of the insect vector in RS reinforces the importance of the fourth factor that stood out in affecting HLB spread risk: difficulties in vector monitoring by growers in their farms. Many citrus growers do not scout for the insect nor control them; thus, the psyllid may occur in the orchards without being detected.

It was evident from our study that few rural properties have phytosanitary certification of origin ( $\mathrm{PCO}$ ), a situation that might aggravate the spread of HLB after its introduction in the state. PCO is a legal requirement aimed at ensuring traceability and phytosanitary compliance in fruit production. In order to get a PCO, the growers must prove they had specialized technical attendance in the field. Thus, it is assumed that when the grower does not have a PCO, technical assistance was also lacking. According to IN 53/2008 of MAPA (Normative Instruction of the Ministry of Agriculture, Livestock and Supply), the movement of host plant propagation material of ' $\mathrm{Ca}$. Liberibacter' spp. from federation units with records of HLB must fulfill legislation regarding sanitary certificates of origin (IN 55/2007) and movement permit (IN 54/2007). Thus, most citrus units would need to adapt to this legislation in order to transport these products, and the absence of any kind of certification is an important factor.

The criterion relating to the lack of citrus farmers organization in cooperatives, associations or unions did not rank among the five most important factors in the composition of HLB 
spread. However, this is of importance because the organization of producers into groups allows the exchange of experiences and the development of common goals, as has been done by citrus growers in the state of São Paulo through regional management. In regional management, the citrus growers adopt joint measures for HLB control in large areas, because even properties that have strict control become uneconomic under high pressure of external inoculum (Bassanezi et al. 2010). Moreover, as pointed by Bassanezi et al. (2010), control of HLB becomes more efficient when producers organize in groups, joining efforts in managing this disease. The organization of citrus farmers in associations and cooperatives can facilitate the management of HLB, considering the probable difficulties faced in RS because of the small size of farms.

The AHP multicriteria analysis method has been widely used to solve problems in a wide variety of areas, applied in research related to decision making in public administration, environmental management, sustainability and agricultural policies (Petrini et al. 2016). According to Bellver and Mellado (2005), its use in agricultural evaluation is of great importance when only qualitative or partial information is available. This method represents a step forward in relation to multi-criteria analysis methods that consider only quantitative variables, since it involves quantitative and qualitative attributes.

The identified priority measures are intended for HLB prevention, since the disease is classified as an A2 quarantine pest in Brazil and A1 in the State of RS. An A2 pest is one of potential economic importance, already present in the country, but presenting restricted occurrence and submitted to an official control program. An A1 pest in one of potential economic importance but still absent within a region (MAPA 2017b). As RS has among its neighbors a country that has records of the disease, as well as frequent circulation of fruit originating from federation units with HLB occurrence, it is essential to develop a more rigid state law, requiring PCO and VTP (vegetable transit permission) to the entry of these cargos. Infected psyllids from these regions can be transported alive for long periods as already known. In addition, there is a need to strengthen the phytosanitary inspection at state borders.

We highlight the need for investments in implementation of training activities, mainly extension, for producers and technicians. The training aims to recognize symptoms and establish basic control practices since early diagnosis is critical to reduce inoculum sources, preventing rapid spreading of HLB. Due to the predominant profile of family farming among RS citrus farmers, it is crucial that measures directed to associations and cooperative work be adopted to facilitate regional management of the insect vector and inoculum source eradication in the case of HLB introduction in the state.

In conclusion, our results suggests that the risks related to both the introduction ( $89 \%$ of the farms) as well as the spread (54.6\% of the farms) of HLB in Rio Grande do Sul's citrus industry can be considered predominantly medium, although the spread risk was considered high in a significant part of the farms surveyed (35.6\%). The most important factors that contributed to introduction and spread risks in the state were respectively, the presence of the disease in a neighboring country and the lack of basic knowledge about the HLB pathosystem among growers.

Acknowledgements To the local offices of EMATER/RS that assisted us in contacting citrus farmers and applying the questionnaires, as well as the Plant Health Service of MAPA, which allowed the access to more distant municipalities. To CNPq and CAPES for the financial support and the Master's scholarship of the first author. To Embrapa Clima Temperado, Embrapa Mandioca e Fruticultura and Fundecitrus for technical support.

\section{References}

Arakawa K, Miyamoto K (2007) Flight ability of Asiatic citrus psyllid, Diaphorina citri Kuwayama (Homoptera: Psyllidae) measured by a flight mill. Research Bulletin Plant Proctection Service, Japan 43: 23-26

Barros MA, Moreira MA, Rudorff BFT (2007) Processo analítico hierárquico na identificação de áreas favoráveis ao agroecossistema cafeeiro em escala municipal. Pesquisa Agropecuária Brasileira 42: $1769-1777$

Bassanezi RB, Lopes AS, Belasque J, Spósito MB, Yamamoto PT, Miranda MP, Teixeira DC, Wulff NA (2010) Epidemiologia do huanglongbing e suas implicações para o manejo da doença. Citrus Research \& Technology 31:11-23

Bassanezi RB, Montesino LH, Gimenes-Fernandes N, Yamamoto PT, Gottwald TR, Amorim L, Bergamin Filho A (2013) Efficacy of area-wide inoculum reduction and vector control on temporal progress of huanglongbing in young sweet orange plantings. Plant Disease 97:789-796

Belasque J, Bergamin Filho A, Bassanezi RB, Barbosa JC, Fernandes NG, Yamamoto PT, Lopes SA, Machado MA, Leite Junior RP, Ayres AJ, Massari CA (2009) Base científica para a erradicação de plantas sintomáticas e assintomáticas de Huanglongbing (HLB, Greening) visando o controle efetivo da doença. Tropical Plant Pathology 34:137-145

Belasque J, Bassanezi RB, Yamamoto PT, Ayres AJ, Tachibana A, Violante AR, Tank JR, Di Giorgi A, Tersi FEA, Menezes GM, Dragone J, Jank JRRH, Bové JM (2010) Lessons from huanglongbing management in São Paulo state, Brazil. Journal of Plant Pathology 92:92-285

Bellver JA, Mellado VC (2005) An application of the analytic hierarchy process method in farmland appraisal. Spanish Journal of Agricultural Research 3:17-24

Bové JM (2006) Huanglongbing: a new destructive, newly-emerging, century-old disease of citrus. Journal Plant Pathology 88:7-37

Castro MEA, Bezerra AR, Leite WA, Mundin Filho W, Nogueira ND (2010) Situação e ações do estado de Minas Gerais frente ao Huanglongbing. Citrus Research \& Technology 31:163-168

Chen J, Pu X, Deng X, Liu S, Li H, Civerolo E (2009) A Phytoplasma related to Candidatus Phytoplasma asteri detected in Citrus showing Huanglongbing (yellow shoot disease) symptoms in Guangdong, China. Phytopathology 99:236-242

Coletta-Filho HD, Targon MLPN, Takita MA, de Negri JD, Pompeu JRJ, Machado MA (2004) First report of the causal agent of Huanglongbing ('Candidatus Liberibacter asiaticus') in Brazil. Plant Diasease 88:1382 
COSAVE (2015) Cosave Region. HLB: Regional Program of Control and Prevention, sem data. Available at: www.neppo.org/wpcontent/uploads/2014/05/cosave - programa_regional_del hlb marruecos_2013110610_12_7.87-MB.pdf. Accessed 24 Dec. 2016

de Carvalho Nunes WM, de Souza EB, Leite Junior RP, Salvador CA, Rinaldi DA, Filho JC, Paiva PG (2010) Plano de ação para o controle do Huanglongbing no estado do Paraná, Brasil. Citrus Research \& Technology 31:169-177

de Oliveira RP \& Carvalho FLC (2016) A situação dos viveiros-telados de citros no Rio Grande do Sul. Available at: www.todafruta.com.br/ noticia/31326/SituaçãodosviveirosteladosdecitrosnoRioGrandedoSul. Accessed 04 Feb. 2016

Duarte J, Barros A (2008) Métodos e Técnicas de Pesquisa em Comunicação, 2th edn. São Paulo, Atlas

EMATER/RS. (2015) Levantamento citrícola. Banco de dados interno

FAO (2017) Food and Agriculture Organization of the United Nations/ Statistic Division. Available at: www.faostat.fao.org. Accessed 23 Jan. 2017

Goepel KD (2013) Implementing the analytic hierarchy process as a standard method for multi-criteria decision making in corporate enterprises-a new AHP excel template with multiple inputs. Proceedings of the international symposium on the analytic hierarchy process. 1-10

Halbert SE, Manjunath KL, Ramadugu C, Brodie MW, Webb SE, Lee RF (2010) Trailers transporting oranges to processing plants move Asian citrus psyllids. Florida Entomologist 93:33-38

Hall DG, McCollum G (2011) Survival of adult Asian citrus psyllid, Diaphorina citri (Hemiptera: Psyllidae) on harvested citrus fruit and leaves. Florida Entomologist 94:1094-1096

IBGE (2017) Sistema IBGE de Recuperação Automática - SIDRA, 2015. Available at: www.sidra.ibge.gov.br. Accessed 20 Jan. 2017

Ikeda K, Ashihara W (2008) Preference of adult Asian citrus psyllid, Diaphorina citri (Homoptera: Psyllidae) for Murraya paniculata and Citrus unshiu. Japanese Journal of Applied Entomology and Zoology 52:27-30

Kobori Y, Nakata T, Ohto Y (2011) Estimation of dispersal pattern of adult Asian citrus psyllid, Diaphorina citri Kuwayama (Hemiptera: Psyllidae). Japanese Journal of Applied Entomology and Zoology 55:177-181

MAPA - Ministério da Agricultura, Pecuária e Abastecimento (2017a). Culturas: Citrus 2016. Available at: www.agricultura.gov.br/vegetal/ culturas/citrus. Accessed 23 Jan. 2017
MAPA - Ministério da Agricultura, Pecuária e Abastecimento (2017b). Instrução Normativa ${ }^{\circ} 41$ de $1^{\circ}$ de Julho de 2008. Lista de Pragas Quarentenárias Ausentes e Presentes. Available at: www.agricultura. gov.br. Accessed 01 Aug. 2017

Martini X, Hoyte A, Stelinski LL (2014) Abdominal color of the Asian citrus psyllid (Hemiptera: Liviidae) is associated with flight capabilities. Annals of Entomological Society of America 107:842-847

Outi Y, Cortese P, Santinoni L, Palma L, Agostini J, Preusler C, Gastaminza G, Perez G, Dominguez E (2014) HLB in Argentina: a new disease outbreak. Journal of Citrus Pathology 1:82

Petrini MA, Rocha JV, Brown JC, Bispo RC (2016) Using an analytic hierarchy process approach to prioritize public policies addressing family farming in Brazil. Land Use Policy, Elsevier 51:85-94

Saaty TL (2008) Decision making with the analytic hierarchy process. International Journal Services Sciences 1:83-98

Saaty TL (2013) Fundamentals of decision making and priority theory with the analytic hierarchy process. RWS publications, $1^{\text {st }}$ Ed. $527 \mathrm{p}$

Sakamaki Y (2005) Possible migration of the Asian citrus psyllid Diaphorina citri Kuwayama (Homoptera: Psyllidae) between and within islands. Occasional Papers Kagoshima University Research Center for the Pacific Islands 42:121-125

Schäfer G, Bastianel M, Dornelles ALC (2001) Porta-enxertos utilizados na citricultura. Ciência Rural 31:723-733

SSV/MAPA (2015) Monitoramento de Diaphorina citri no Rio Grande do Sul. 2015. Banco de dados interno

Teixeira DC, Danet JL, Eveillard S, Martins EC, Jesus JRWC, Yamamoto PT, Lopes SA, Bassanezi RB, Ayres AJ, Saillard C, Bové JM (2005) Citrus huanglongbing in São Paulo state, Brazil: PCR detection of the Candidatus Liberibacter species associated with the disease. Molecular and Cellular Probes 19:173-179

Teixeira DC, Wulff N, Martins EC, Kitajima EW, Bassanezi R, Ayres AJ, Eveillard S, Saillard C, Bové JM (2008) A phytoplasma closely related to the pigeon pea witches-broom phytoplasma (16SrIX) is associated with citrus huanglongbing symptoms in the state of São Paulo, Brazil. Phytopathology 98:977-984

Tiwari S, Mann RS, Rogers ME, Stelinski LL (2011) Insecticide resistance in field populations of Asian citrus psyllid in Florida. Pest Management Science 67:1258-1268 